Andrews University

Digital Commons @ Andrews University

\title{
Strengthening Social Bonds in Bujumbura Through Public Space: Redesigning Jardin Public de Bujumbura for the Restoration of the City's Sense of Community
}

Gwendoline Albright Ndikumagenge

Andrews University, gwendolinea@andrews.edu

Follow this and additional works at: https://digitalcommons.andrews.edu/honors

Part of the Architecture Commons

\section{Recommended Citation}

Ndikumagenge, Gwendoline Albright, "Strengthening Social Bonds in Bujumbura Through Public Space: Redesigning Jardin Public de Bujumbura for the Restoration of the City's Sense of Community" (2019). Honors Theses. 196. 


\section{J. N. Andrews Honors Program Andrews University}

\section{HONS 497}

\section{Honors Thesis}

"Strengthening social bonds in Bujumbura through public space:

Redesigning Jardin Public de Bujumbura for the restoration of the city's sense of community"

\section{Gwendoline Albright Ndikumagenge}

April 5 $5^{\text {th }}, 2019$

Advisor: Prof. Andrew Von Maur

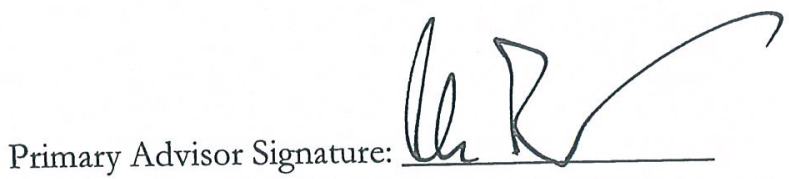

Department: School of Architecture and Interior Design 


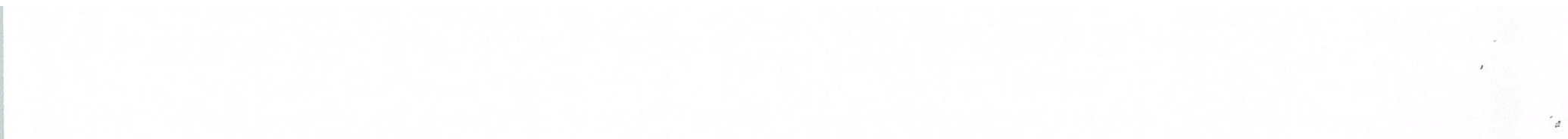


"In every community, there is work to be done. In every nation, there are wounds to heal. And in every heart, there is the power to do it.

\section{- Marianne Williamson}




\section{Content}

Dedication

Abstract

Forward and Preface

I. Introduction

A. History of a country at a crossroad

B. Problem statement

C. Park as an instrument for social incorporation and identity of a community

II. Investigation and analysis
A. Site description and current situation
B. Neighborhood analysis
C. Climate design factors

III. Raw materials for the toolbox

A. Literature reviews

1. The placemaking analogy

2. A public-yard design principle

3. Essential principles for the toolbox

B. Case studies

IV. Tool Box
A. Toolbox concise
B. Design principles and design patterns
C. Additional tools recommendations

V. Summary and conclusion
A. Discussion and limitations
B. Future recommendations

Bibliography 


\section{Dedications}

I wish to dedicate this piece of work to the Almighty God who has enabled me to realize every part of it. I also dedicate this senior year thesis to my father, my beloved brothers, my sister, and my family members for their support and help in everything that I needed to complete this project. To all my friends and church family who continuously prayed for me, thank you. I also dedicate this report to my advisor Professor Andrew Von Maur, Professor Jacques Nkengurutse, Mrs. Carmen Nibigira, the Andrews University School of Architecture and Interior Design, and the J.N. Honors Department for giving me the opportunity to carry on such a project while providing all the resources, guidance and motivation that I needed to complete it. Last but not least, to my lovely mother whom I look up to every day, a special appreciation and acknowledgment for her continuous support, guidance, and help through it all. Thank you, mom! 


\begin{abstract}
In the last century, public spaces have been of the most studied elements in urban design as some of the most used and impactful places that shape public life. Unfortunately, the necessity of public spaces for the years, like Burundi, the public realm is often have continuously experienced war and instability over of the city's well-being. Public spaces are seen as peived as a source of problems rather than a promoter and instabilities in the city. This project seeks to settings that contribute to an increase of insecurities existing public space using design principles and patterns into possibility of intentionally redesigning an promote positive public life in the city. It will consist of into a well-designed space that would help patterns that can be used in the redesigning of underutilized parks in Burundi, with the hope neighborhood in Bujumbura.
\end{abstract}

Keywords: Jardin Public, Bujumbura, Placemaking, Principles, Patterns, Tools. 


\section{Forward and Preface}

\section{My introduction to the Public Realm.}

I had never been so interested and heard so much about public spaces before joining Andrews University School of Architecture and Interior Design to get my degree in architecture. During my years at Andrews, I learned about public spaces as places where people meet and connect; places where memories are created and as places that could reflect a region's identity. Through lectures and books about public spaces, I studied their use and impact on the region when intentionally well-designed. Moreover, this created in me a great interest in the topic.

Growing up in Burundi, I had never experienced such places that I would identify as public space. Back home, public spaces were limited to schools' playgrounds, family house courtyards, and neighbor's house gardens. Therefore, to me, the professors' definitions of public spaces and how they contribute to communities' wellbeing always sounded exaggerated. So, I imagined that I simply had to learn to understand the impact of public space design on communities.

According to Francis Violich, an intuitive and comparative style of urban space helps reveal how unique environmental context plays a significant role in generating a sense of place. I would not have understood what that meant before I had the chance to experience what a sense of place meant to me. While in the Analytical Summer Abroad class in the summer of 2018, I had the chance to experience and explore several public spaces in different countries. It was like living in a dream. I had "deja-vu" moments in these places because of all the times I had to imagine them in class without understanding them (Violich,1885).

It was my first time to see people gathered in places where they were not required to be. Even though most of the sites we visited were mostly touristic sites, it looked like about $85 \%$ of the people were locals. For example, in France, I was amazed to find places like Jardin du Trocadero full of people just sitting down on the grass, mingling, enjoying the breeze or the beautiful view. People would come to spend hours in these spaces just hanging out on the grass as more people joined them.

The most impactful moment that I encountered while exploring public spaces in Europe was when I had the chance to witness a friendship being built in a couple of minutes between two kids who happened to meet in a square called "Jean XXIII" behind the Notre Dame Cathedral in Paris. Usually, in our culture, people do not meet other people randomly and start talking with them; it is forbidden in other culture. I remember being warned as a child to not talk to strangers, yet, these places gave reassurance and a sense of security to parents/guardians that they let their kids engage and make friends randomly.

Can you imagine how many friendships were formed in such places as these? Alternatively, how many couples met there and now formed families? Unfortunately, for people who did not get the chance to grow up with areas like these around, we tend to conclude that public spaces are not necessary. Moreover, sometimes we see them as a waste of land because we do not apprehend their worth.

I used to complain about how much time our teachers would spend teaching us about the roles and the concepts of public spaces. I remember spending weeks with professors trying to come up with the best design for the entrance of a building, only because of a public space I decided to put in front of it. I never understood why they would stress so much on how well public spaces had to be designed. However, after 
seeing what these places could bring in communities, I doubt I can design any building or space without
getting excited about where to put the corresponding public space.

\section{Introduction}

\section{A. History of a country and the place}

Burundi, located in the heart of Africa, is one of the countries that was a kingdom before it became colonized and then evolved into a republic. It was a kingdom with a structured administration which later became colonized and ruled over by both Germany (before the 1st world war) and Belgium after. Back then, the colonialists formed towns and cities for administrative purposes and trade, for their political domination and colonial business enterprises. In Bujumbura, the capital city of Burundi, several neighborhoods were established then. They were established for precise reasons and intended for specific users. For instance, Rohero I, where the Jardin Public is located, was designed to be more residential and contain urban spaces like parks, unlike others that were more commercial or industrial
oriented.

The established neighborhoods during the colonial time were 13 in total and were originally designed according to the intended inhabitant background or economic class. There were specific neighborhoods for European communities, Asian communities, for national cadres called OCAF (Office des Cites Africaines); there were also neighborhoods for mixed foreign African workers and so on. When these neighborhoods were established, five main places were created in each one of them: 1.a school, 2. a hospital, 3. residences, 4. a market place, and 5. an amusement park or garden. Jardin Public was the amusement place/ park that was established in Rohero I for the white colonialists.

With a Gross Domestic Product (GDP) per capita of 309 US dollars in 2018, Burundi ranks among the ten poorest countries. One of the reasons for Burundi's current poverty is the ongoing strife of ethnic-based tensions and civil instability. Since its independence in 1962, it has been overwhelmed by the tension between the Tutsi minority and the Hutu majority fights. The official civil war that sparked off in 1993 was never resolved and lead to more war outbreaks. I remember growing up in a city that was never safe to walk in at any time of the day; where no one ever knew that they would make it to the next day because of the unpredictable gunshot and bombing in the city.

Down the street from my childhood house, one of the streets that I used to walk in when going to school every morning was on the side of the neighborhood's public park "Jardin Public de Bujumbura." This park, however, because of the country's security condition had become a no-go place for people, especially children. Hence, the park that was designed and established for the greater good of the neighborhood and community became an underutilized place and was perceived to be a den of thieves, assassins, and rapists. The park then had turned into a wasteland after years of not being taken care of. It was then supposed to be a corrupted and dangerous space because of people who would get killed, raped or robbed in that area. For years, developers look at it as a waste of land that could house a multifunctional building or houses that would help the economy of the country. However, as a designer, I see this place as an overlooked opportunity to become a vessel for the healing of the country.

I consider architecture as a profession with countless problem-solving tasks and opportunities. Thus, this project aims at seeking and examining the possibility of such a public space to be redesigned to contribute to Bujumbura's necessity of becoming peaceful and secured again. The project is an 
opportunity to use my architectural expertise and knowledge to propose a solution to my home country. It will create a possibility for Burundian next generation to be able to live the dream that I dreamt as a child. My goal is to gather tools that could aid a redesigning process for Jardin Public, creating a public space that can help restore the city's sense of community and revive Burundi's hope for a safe city.

With the help of different pattern and principles, I wish to come up with the prominent tools, that when implemented, would change the reputation of the public space in Burundi. I chose "Jardin Public" park not only because of its location at the center of Bujumbura but also because it personally resonates with me, a part of my childhood. Therefore, by studying and implementing certain language patterns and principles, this project will enable an intentional redesign of Jardin Public giving it the possibility to impact its community positively.

\section{B. Problem statement}

Jardin Public de Bujumbura, spread over six hectares of land in the middle of the neighborhood of Rohero I. was historically a public amusement park that had become a no-go place because of being underutilized and not maintained for a long time. The park was rehabilitated in March of 2009 with the support of the French Embassy and the ACVE (Association Century Verte pour l'Environnement) after having been occupied for several years by fields and pastures. Their wish was to bring more life and utility to the park. It is now used as a public-private park, owned by the government with an access control of an entry fee due to various reasons including maintenance fees (See figure 1).

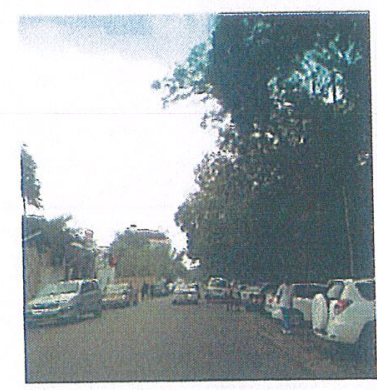

Parking on the streets unar the entrance

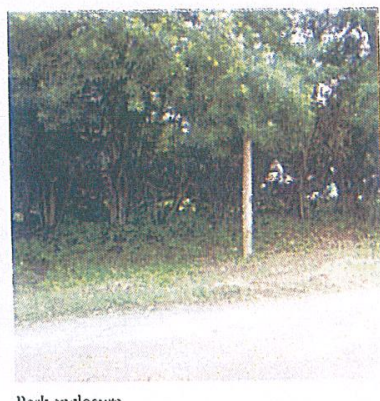

Park enclosure

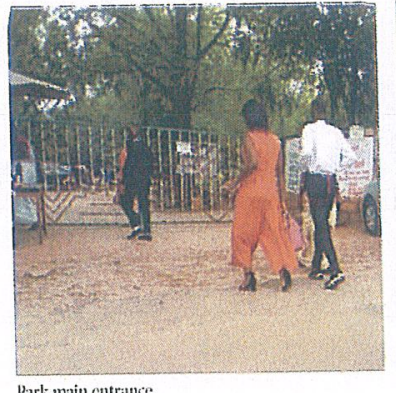

Park main cntrance

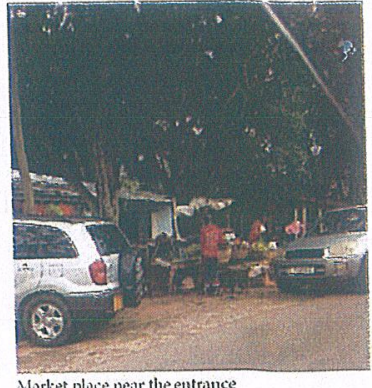

Market place near the entrance

Figure 1: Street view photos.

Nevertheless, there is still a threat to the development of the place not only as an urban space but as a commercial space from potential developers. Urban developers perceive the park as inhabiting more land than it should; to them, the lands could be redeveloped and bring additional revenue that could contribute to the country's economy. However, as a designer, it would be a loss of the land's original function in the community; hence a missed opportunity to use it to its fullest potential. The project aims at studying ways in which this park can be not only maintained but redesigned intentionally using suitable patterns and principles empowering the park with tools that would contribute to the healing of Bujumbura's inhabitants while bringing back Bujumbura's sense of community.

\section{Park as an instrument for social incorporation and identity of a community}

Neighborhood parks, even though might have different programs, activities or even goals, they usually play almost the same role in a community. They are mostly there to enhance the community's bonds, 
promote and accelerate social, cultural and ethnic understanding and integration of the people in the
community.

Most studies about urban spaces discussed the influence of places for leisure and recreation that these spaces provide in communities to affect people from different ethnic and social backgrounds. The studies are proven to have a potential to can be more inclusive than non-park places. Therefore, urban spaces inter-ethnic tensions and thus act as inte social interaction between different social groups and reduce where people from different background can bil social cohesion since such spaces can become places

of them showcase the identity parks and urban spaces around the world are parks that tell a story. Most and the uniqueness of the place, then place or community, they communicate and explain the history developing countries, most urban spaces host instead of accommodating communities' daily activities events and represent a memorial occasion programs in one.

A number of cities and neighborhoods, especially in the developing world, are still lacking opportunities to establish more of public spaces and often lack the understanding of how special, needed and useful future of the country. One such city is Bujumbura.

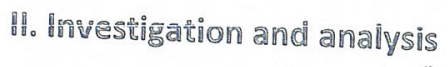

\section{A. Site description and current situation}

Burundi, with an area of $27,834 \mathrm{~km}^{2}$ (slightly smaller than the U.S state of Maryland), is a landlocked country in the east of Africa with 11.4 million habitants, and where Bujumbura is the largest and capital city with a population of about 332,000 (2009) (See Figure 2).

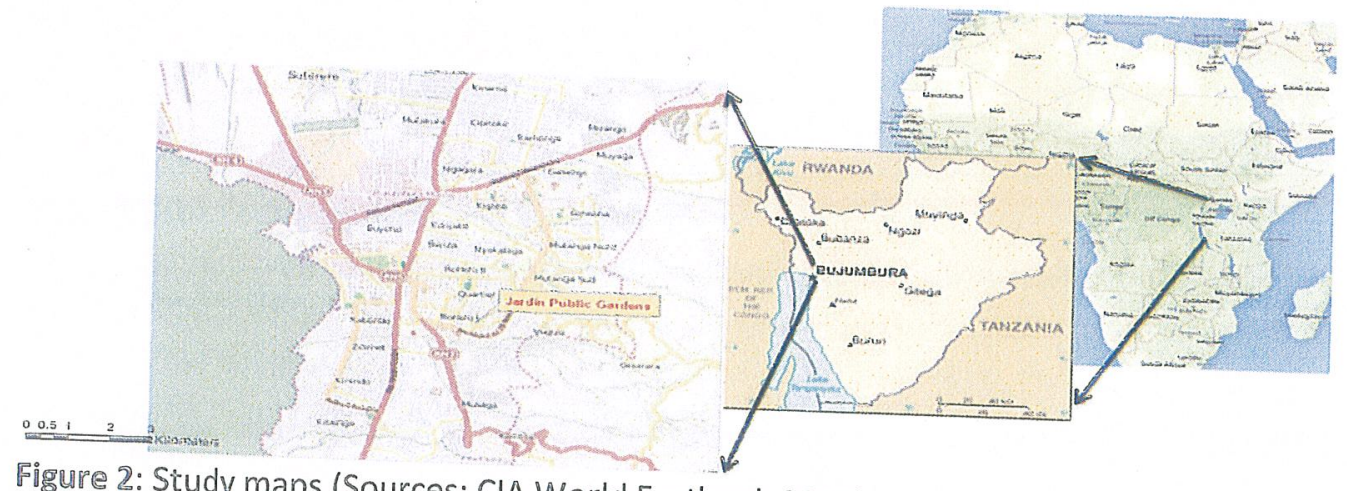

Figure 2: Study maps (Sources: CIA World Factbook,2015)

In the heart of Bujumbura, the capital city of Burundi, Jardin Public is spread over six hectares approximately 700,000 sq. Ft of land in the commune of Mukaza, zone of Rohero. In Rohero I neighborhood, Jardin Public is within a 5-minute walk radius to many residential houses, offices and 
facilities. It is also in a 10-minute walk radius to the city center of Bujumbura and in a walking distance from one of the principal roads of the city that connects most of the principle neighborhoods of the city: Boulevard du 28 Novembre (See Figure 3).

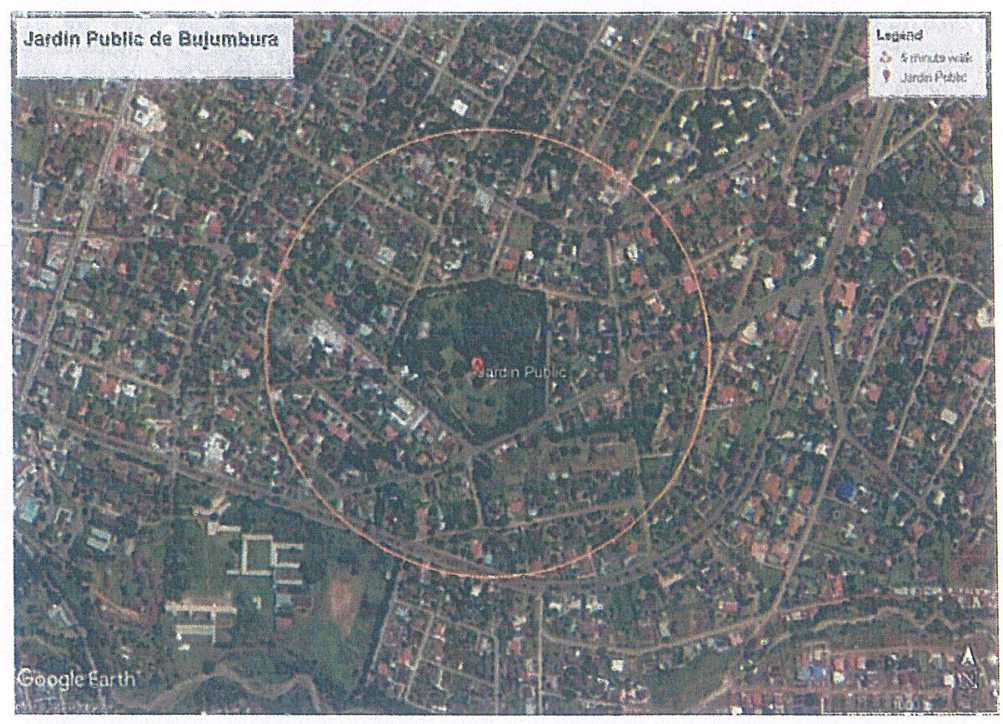

Figure 3: Aerial Map \& 5-minute Walk circle.

As mentioned in the problem statement, the park is currently being taken care of by the ACVE (Association de la Ceinture Verte pour l'Environment) which took upon the responsibility of managing the park and maintaining it for its users. Also, by commiting to spend a big amount of money in the rehabilitation project of the park, the association hopes to see this park developed in such a way that it will attract more users to fulfill its original role as a neighborhoods' park. Below is a plan that was proposed to attain this goal (See Figure 4).

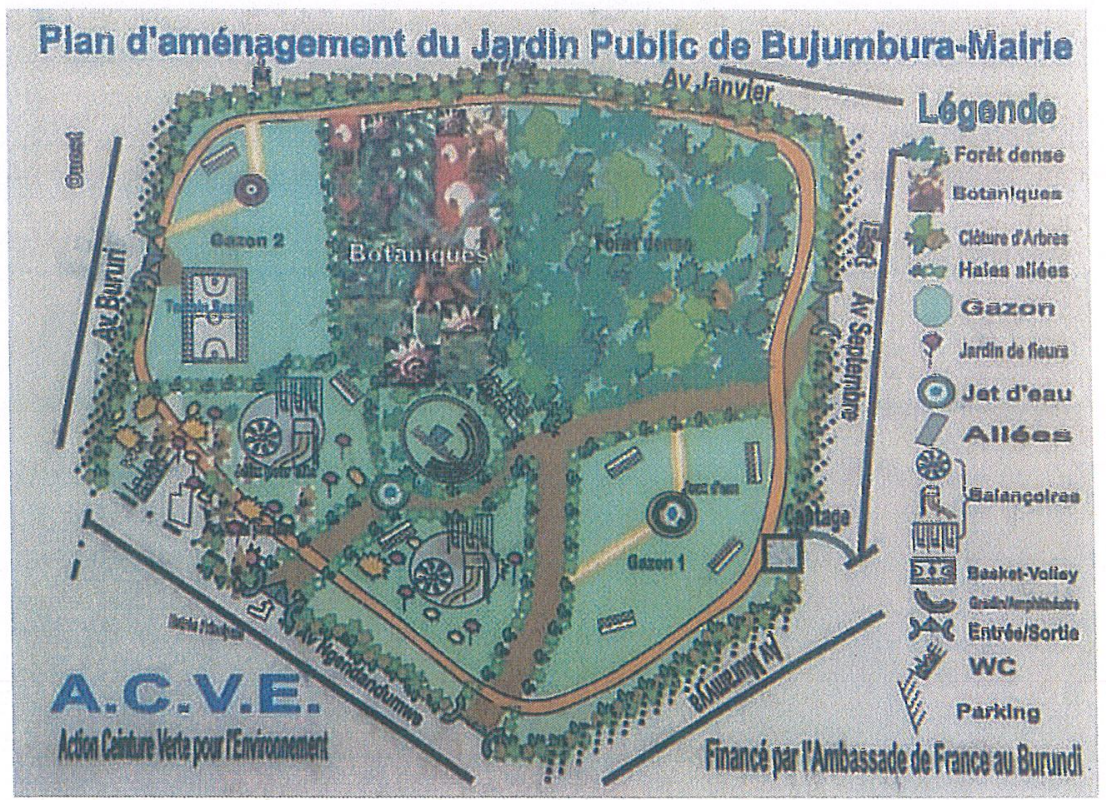


Figure 4: Plan d'emenagement proposed by ACVE.

\section{B. Neighborhood analysis}

One core reason to why I chose to base the project in Jardin Public de Bujumbura in Rohero I is that it is to date one of the safest neighborhoods in Bujumbura yet close to other neighborhoods that are not as safe. It is located close to the downtown of Bujumbura where all the life happens, and close to Kiriri which is the upper class and presidential neighborhood (where the President of the republic lives). Therefore, the park would be a potential geographical liaison between the two worlds of Bujumbura's upper-middleclass community and lower-class community, as shown in the context map below.

To better understand the urban design and planning of the place as well as the neighborhood density, a study with the use of a figure-ground diagram was used. It enabled the research to further identify the traffic density around the park as well as the type of activities that take place around the park. It also allows an understanding of the land use of urban development in the neighborhood. This analysis helps to understand whom I am designing for and how the project will be relevant to the neighborhood. (See Figure 5)
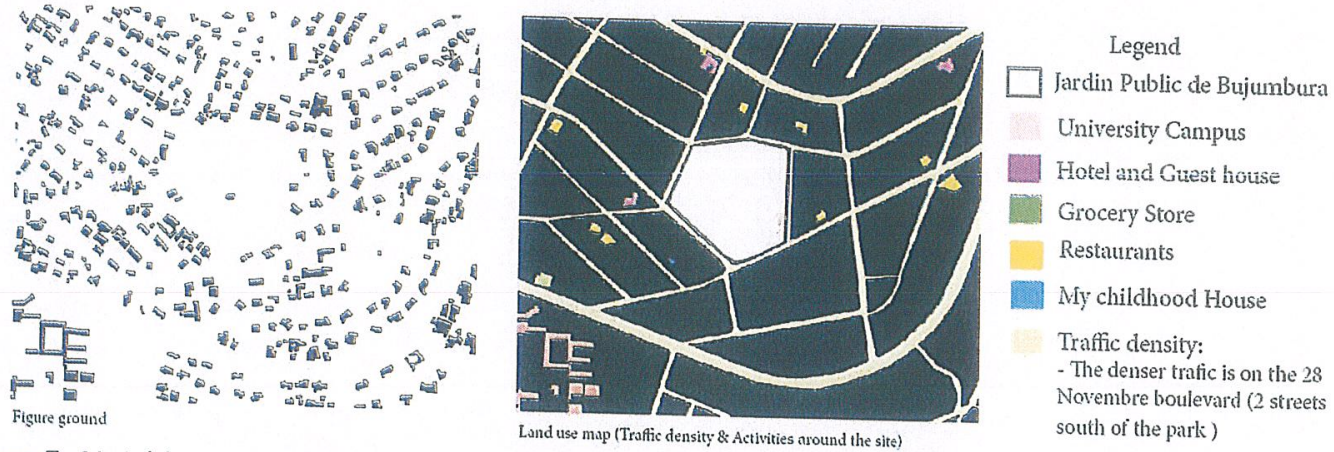

Figure 5: Neighborhood study maps.

\section{Climate design factors}

Burundi is a small landlocked country located just south of the equator (GPS coordinates: $3^{\circ} 30^{\prime} \mathrm{S} 30^{\circ} \mathrm{O}^{\prime} \mathrm{E}$ ) on the northeastern shoreline of Lake Tanganyika with a mild or warm climate. The maximum temperature is around $84^{\circ} \mathrm{F}$ all year round, except from mid-August to October, when it reaches $86 / 88^{\circ} \mathrm{F}$
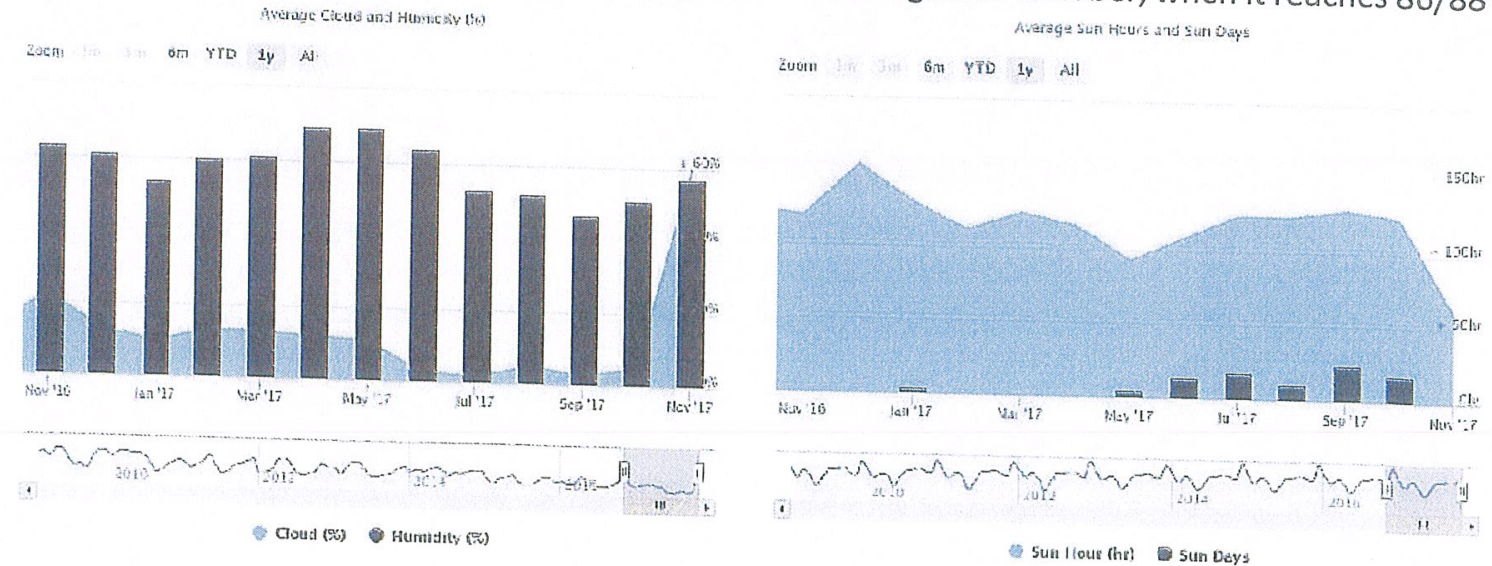
(See Figure 6). Much of the country is occupied by a plateau, at an altitude of around 5,000/6,000 feet above sea level. (Sources: World weather online, 2019)
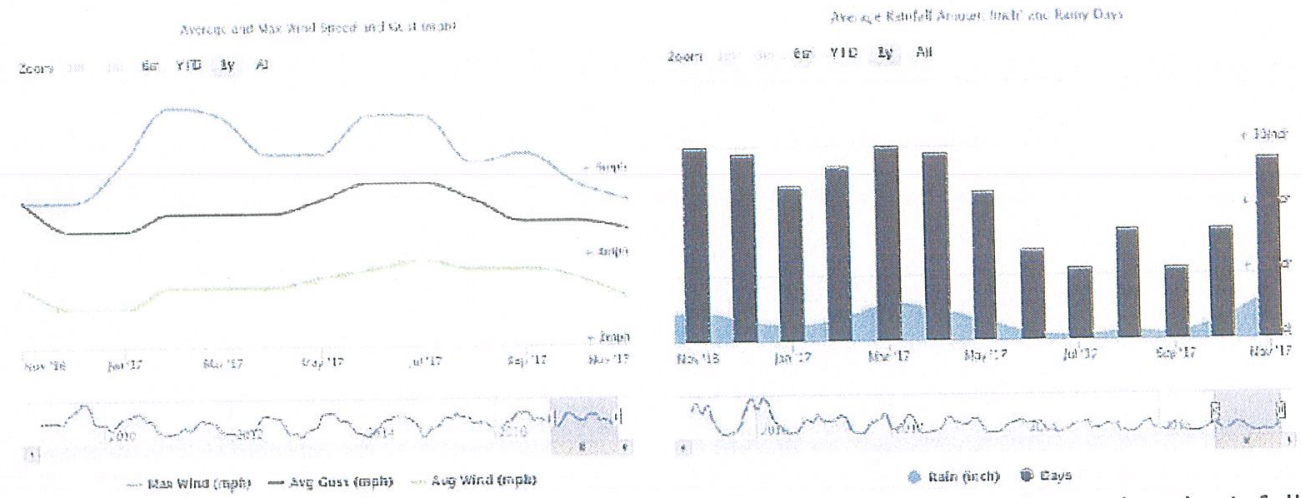

Figure 6: Climate factors charts: cloud \& humility, Average sun hours, wind speed and rainfall.

\section{n1. Raw Material for the toolbos}

"We are never going to save the rural places, or wild places or scenic places unless we identify the human habitat, and then strive to make it so good that humans will voluntarily inhabit it."

-James Howard Kunstler

\section{A. Literature review}

\section{The placemaking analogy.}

It is very rare to discuss what Urban spaces are or ought to be without discussing the implication of placemaking. According to recent studies, public spaces are in decline and are being replaced. Traditional connections, conversations, and interaction that used to happen face-to-face in public spaces are now happening on the internet. According to an article about this decline or the urban spaces crisis that is happening, the author argues that "square spaces of the world are replacing public squares." As one of the goals of this study, I question whether such studies are alert calls to us designers to intervene and revive these places with the placemaking analogy or concept (Toloudi,2018).

I believe that as long as it becomes clear to architects of my generation that the public realm is the missing piece of community design, the public realm can be revived in such a way that it becomes a communities' oasis. Research and studies about urban design have proven that the urban design theory has gradually developed and designers are leaning towards using placemaking approaches when designing urban spaces. It is with a community-based active space in mind, and a people-centered approach of planning, design, and management that designers can discover the actual needs and aspirations of the community. Moreover, it is only by then that they would be able to create a public space of a quality that could contribute to people's health, happiness and wellbeing.

As an all-encompassing concept and approach to improve a neighborhood, a region or a city, placemaking is believed to inspire people to reimagine or reinvent public spaces as the heart of their communities. Therefore, common problems like underutilized parks, traffic dominated streets and other urban problem could be avoided by merely implementing a model of placemaking. In that process, strengthening bonds 
between the people through the places that they share -- placemaking in other words -- should be viewed also can facilitate the which designers can shape public realms to maximize shared values. Placemaking the social identities that define pattern of use through paying attention to the physical, the cultural and

\section{A public-yard design principle.}

Placemaking is not a new idea; it has been a studied subject from the mid-1990s and remains of interest. The analogy of placemaking gained attraction when people(writers) like Jane Jacobs and William $\mathrm{H}$. Whyte introduced ideas about designing spaces for people. Their work focused on how to intentionally design spaces to fulfill the social and cultural needs of a lively neighborhood. Jane Jacobs introduced ideas like encouraging people to take ownership of the streets through concepts like making streets more visible in and out in relationships to buildings, while Holly Whyte outlined critical elements for creating lively social
spaces in public spaces.

Jane Jacobs in her book: The death and life of great American cities discusses the likelihood that the physical arrangement of a neighborhood affects the neighborhoods' park physically in addition to various design tools that make the park viewed as a public-yard design. She confirms that the mixture of users of buildings or houses around the park directly produces a mixture of users for the park but that four elements characterize an urban space design that can be considered as a public-yard space. These
elements are intricacy, centering, sun and enclosure.

To better serve the users of urban spaces in case the neighborhood is contributing to the mixture of users to mentioned above, Jane Jacobs discusses the need of intricacy in the design of the park. Intricacy refers to the variety of reasons and opportunities for which people come to respective parks at different times for different activities and in pursuit of different desires and satisfactions. Nevertheless, even if most successful parks are known by how they look more intricate in the use and diversity of users, the principle of centering is very important to understand so that the users can orient themselves within it. She also escape when needed. finding great importance in the en sustainability.

An enclosure is often directly interpreted as a fence or an entry fee. However, as Jan Gehl argues in his book The Cities for People, there are many other ways to design an enclosed park especially considering the concept of the city at eye level. This principle can also be explained through Jan Jacobs' principle of eyes on the streets. The general idea here is that people want to see where they are going and will feel more welcomed when everything is designed down to their scale. From this principle, Jan Jacobs discussed comfort, and protection the scale mattered too in the concept of reoriples concerning the traffic flow and human contact or simply

\section{Essential principles for the toolbox.}

Parks' unpopularity or underutilization does not only depend on the waste or missed opportunities that they might infer, it can also be linked to the negative effects that they are perceived to bring into the neighborhood and communities. A research that was done in 2017 about Jardin Public's current situation 
and its users' appraisal shows that, though Jardin public de Bujumbura is highly valued by its users, safety and security is still a significant concern for most users. The Burundian community is traditionally known to be a very social community that loves gathering to celebrate social events like weddings, births, mourning periods and so on. Therefore, providing a space where the community could enjoy an adequate space for celebration, social interaction and bonds would be ideal. However, considering the concern of safety stated above, the redesigning of the Jardin Public would include and not limited to principles like "eyes on the street," delight, comfort, and protection as well enclosure as defined by Jane Jacobs (Kitheka, 2017; Jacobs, 2016).

The research also reported that even though the parks' users are found to be satisfied with its current situation in terms of programs; they call for more intricacy, for instance an increase in the number of play and recreation programs for all ages to fulfill a variety of needs and expectations by the users. Other suggestions and concerns that were stressed by the study report were that the park users cry for an increased effort towards the protection of the park as well as the maintenance of the gardens and facilities, which can be translated as a need for a reordering of priorities.

Furthermore, to redesign this park efficiently and with all these principles in mind, the study of the park's location, climate factor, and history would help the designer in their premise towards the redesign of the park. For instance, the need of the climate factors that was done provides a better understanding of how and why the future designer of the park will need to consider the principle of Sun. An analysis of the neighborhood would help in the implication of the principles both of intricacy and centering.

\section{B. Case studies.}

To accomplish a deep study about the possibilities of redesigning Jardin Public de Bujumbura, I took the liberty of consulting a variety of similar urban parks located in different places around the world. This enabled me to examine and understand the work and implementations of the principles mentioned in the literature review above. I intentionally picked six parks in 3 different continents that have some criteria that can be related to the current situation of the Jardin Public de Bujumbura in terms of scale, history, design purposes and so on. The parks selected encompass to some extent elements that could enable Jardin Public to become a more efficient park, if redesigned with a level of intentionality.

I decided to study different spaces in different locations around the world because it would enable me to think outside the box when assembling the tools for the park's potential redesign. It would also help in reducing the limitations that could rise when accessing on alternatives of using the suggested tools, principles and their application from the parks studied. These measures would include, but not be limited to the difference in weather and climate, the economy of the places, the community history represented by the park, the population density and so on. The ultimate goal is to study various criteria of the existing parks through principle and value of their design to inspire the tools that would go in the toolbox. Below are the selected case studies:

i) Parks selected from Africa (White, 2015).

Since this research is based in Burundi, a country in Africa, I studied parks that can relate to Jardin Public in terms of the historical aspects and the location factors. Though Africa has for the longest been perceived as a continent of small villages in the jungle or savannah, the worlds' updates show that its 
urbanization is advancing rapidly. African cities and metropolitan regions are among the fastest growing and developing places in the world today, according to Gary White who took the time and effort to map urban forms and structures of African cities describing and illustrating the why and how they were
established.

Among the African countries that Gary White in his book African drawn describes, I chose two parks that have some of the features that can be considered as tools that help these urban spaces to be successful through the principles discussed in this study.

The first park I considered is a park in Mogadishu, Somalia is known as a park or holiday garden called Beerta Nasashada Park. I chose this particular park because of its reason of existing and its unique design that seemed to be very intentional. The park has a great way of explaining what Jane Jacobs mean by

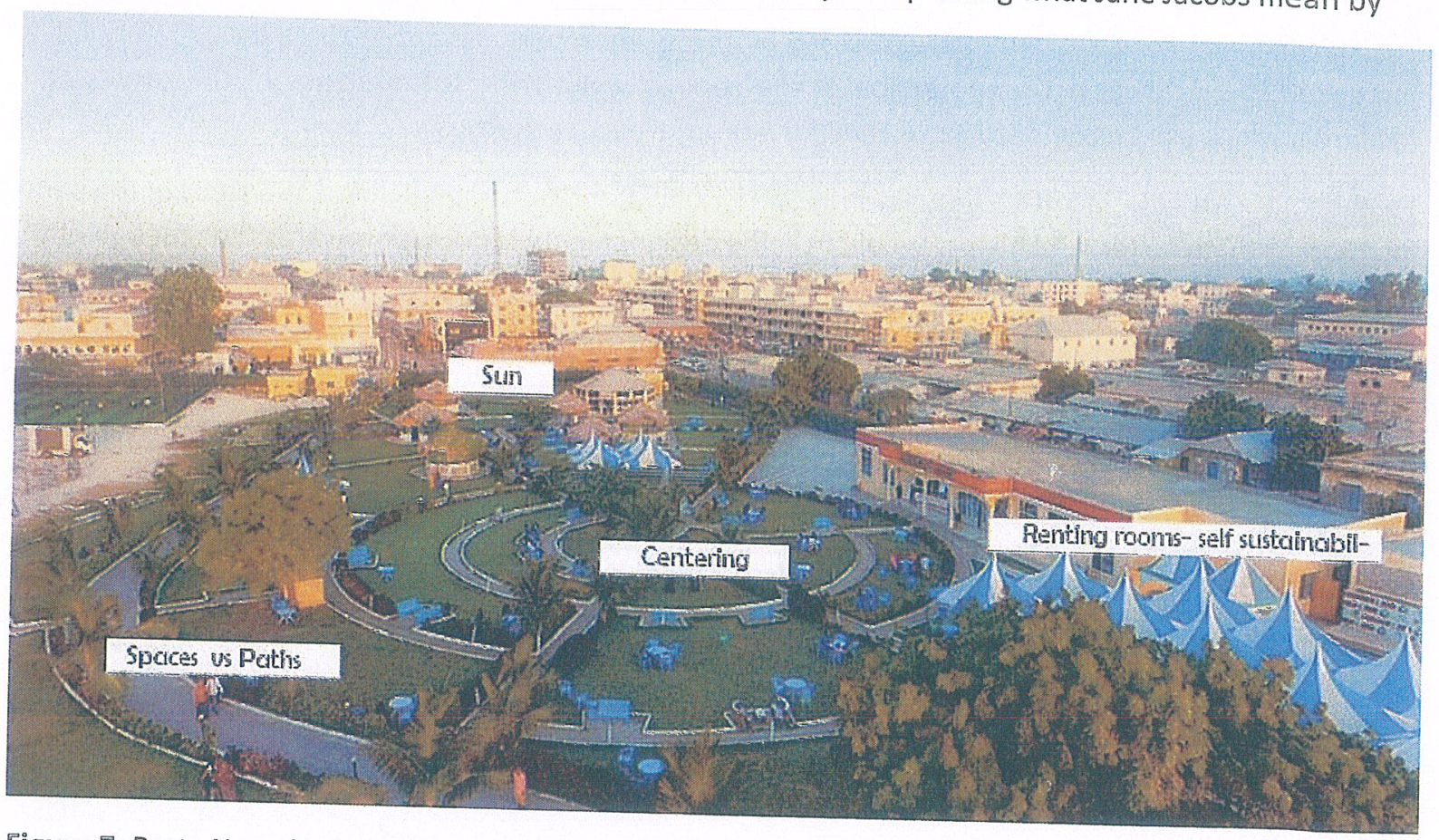

Figure 7: Berta Nasashada Park, Mogadishu, Somalia 
The second urban space that I chose is one in Cape Town, South Africa that is called the Green Market Square. My interest in this park is associated to its design features and its historical characteristics. This particular square was originally a slave market that the people turned into a public urban space with spaces where they advocate a health maintenance life style. This square is an excellent example of a plaza that is intentionally designed for a specific goal and has features that can be acknowledged to be tools that help the place attain the sun principle.

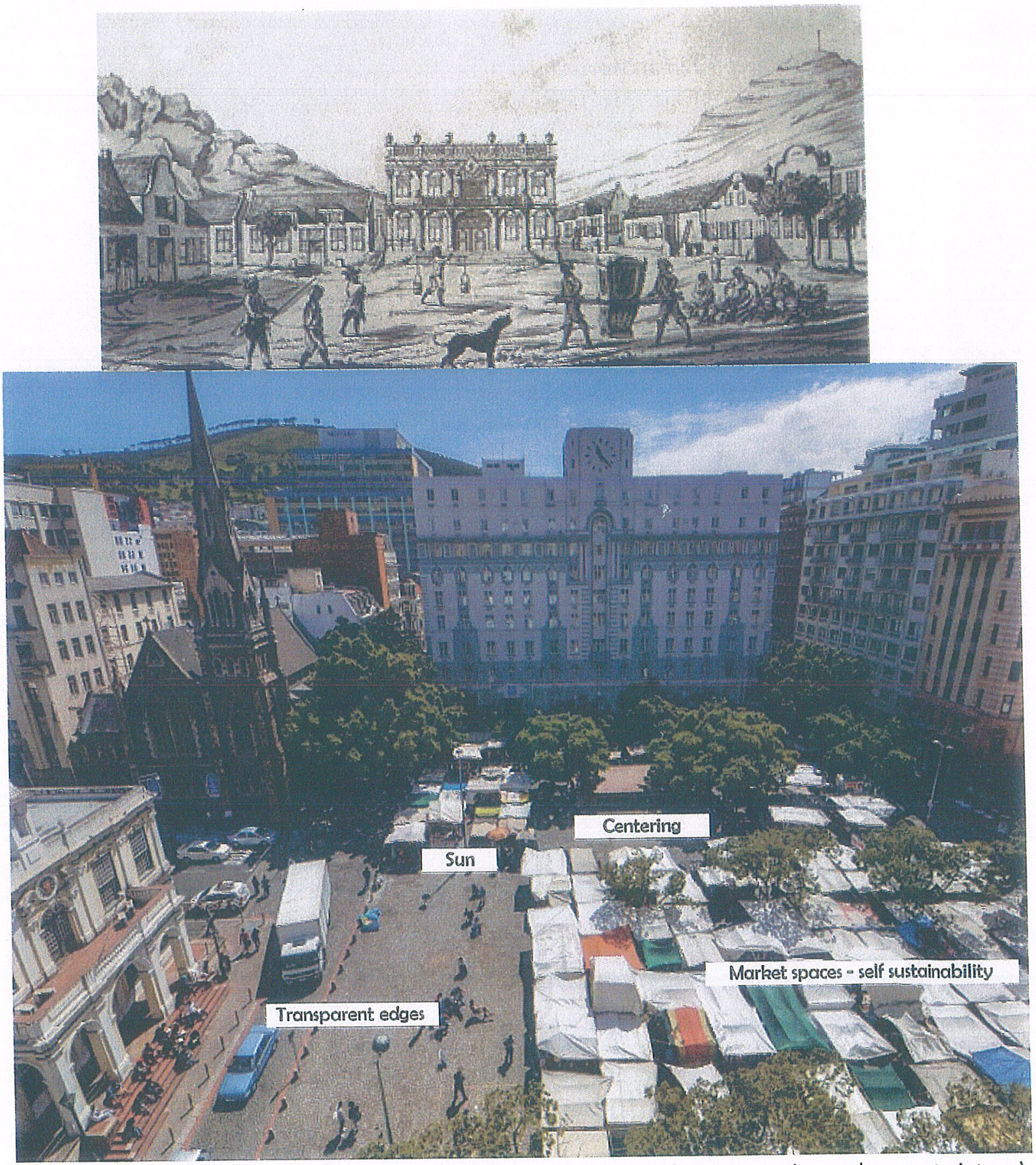

Figure 8: Green Market square, Cape Town, South Africa (a historical reconstruction and present picture). 
These two parks in addition to proving the principles described by the literature reviews used, they also present some design patterns and tools in their design and the sense of place that they have. Some of thes. paths, sun, centering, transparent edges, and self-sustainability.

ii) Parks selected from Europe.

Europe has a long historical narrative of classical, medieval settings where plazas and urban spaces hosted a wide variety of socio-economic and recreational functions. Moreover, as I mentioned in the preface, the summer of 2018 was very educational. The visit got the chance to visit during my trip to Europe in the in the idea that urban public spaces have the potit to those different urban spaces persuaded me to believe Though

Though most of the parks in this continent have unique aspects that can be considered as case studies in the two parks selected have a powerful way of chent countries to use as precedent studies. In my opinion, programs.

The first park in Europe that I studied was a park that has roughly the same square footage as Jardin Public (only about 1 hectare more) and has similar essential features such as the vegetation, yet, has more neighborhood and in the whole city and garden in the city center of Dublin. This public in Dublin, Ireland is a four centuries historic park neighborhood. In addition to providing the us public park is very significant to the city, and the interaction opportunities; the park also showcases the histh places to play, and recreational and social sculptural monuments in Irish history. 


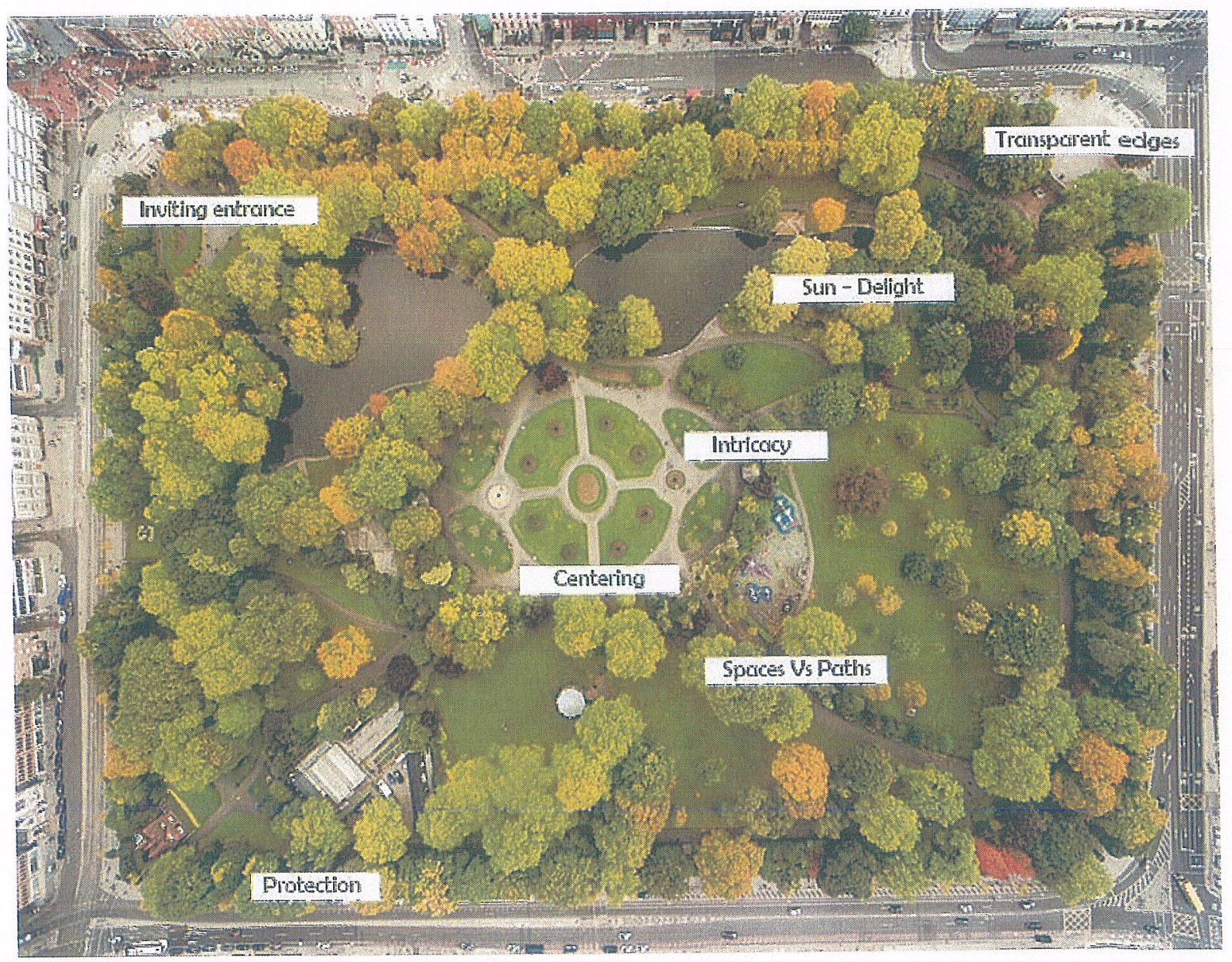

Figure 9: Stephen's Green, Dublin, Ireland.

One thing that is often discussed in architecture and mentioned in the design theory of spaces is the accessibility aspect of places. The first things that come to mind when talking about accessibility and how to design spaces is how to accommodate people in wheelchairs. St. Stephens Green park took this aspect to the next level in addition to having a sense of place that expresses delight, comfort, and protection; it was the first park that I have ever heard of having a garden designed specifically for blind people. This can be viewed as a result of using Jan Gehl's principle: reordering of the priorities, in the park's design.

The other park that I considered in Europe is a park in Berlin, Germany that has features that are found in the existing Jardin Public such as the runways/walkways; yet again, it is better designed and is known to be more efficient to its users. Am Gleiesdreieck is one famous park in Germany that received the German landscape architecture prize in 2015. The prize was received considering its outstanding quality in design and construction through a detailed planning. It is also known for its preservation of the ruderal flora which ties to the original history of the place. (Park at Gleisdreieck. 2016) 


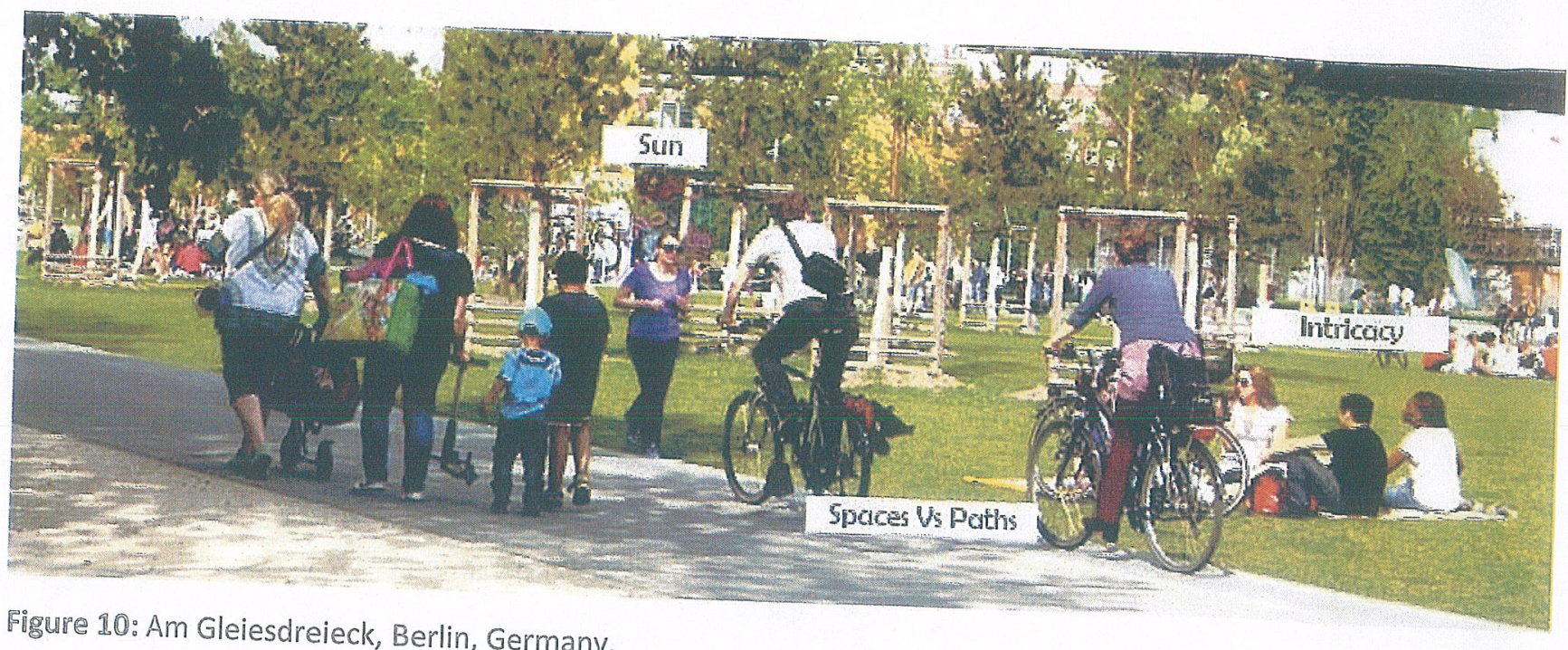

Figure 10: Am Gleiesdreieck, Berlin, Germany.

It provides the users with many activities to do while in the park, that it attracts a variety of users namely children, athletes, skaters, families, historians, tourists, and so on. It has a perfect sense of space and promotes centering as well. The aim and goal of the way this park was designed and continues to be maintained are to preserve and show Berlin as a multi-cultural, sophisticated, modern, flexible, fun loving
and above all sensual city.

These two parks in addition to having a great way to express some of the principles that make them unique and allow them to fulfill their goal both as urban spaces and as city parks; also raise the pattern of ldentity as one of their objectives that I believe that Jardin Public strives to have. This pattern would help promote

iii) Parks selected from the United States.

The United States of America has had many people researching and studying the impact of urban space in cities since the '60s. Jane Jacobs was one the pioneers of that movement in the quest to make great cities where she involved their urban aspects.

Rittenhouse square was one of the urban spaces that she used to illustrate, discuss and demonstrate her theory about urban spaces. I chose this square because the park is well designed and is very influential as park outstanding Jacolos' book. In fact, the characteristics that she discusses in her book that make this intricacy at eye level which should be still present to date. She describes it as an excellent park with considering how small this square is compared to Jardin Public (Rite project of redesigning Jardin Public which means that the same efficacy of Rited to Jardin Public (Rittenhouse square is 3 times smaller); 


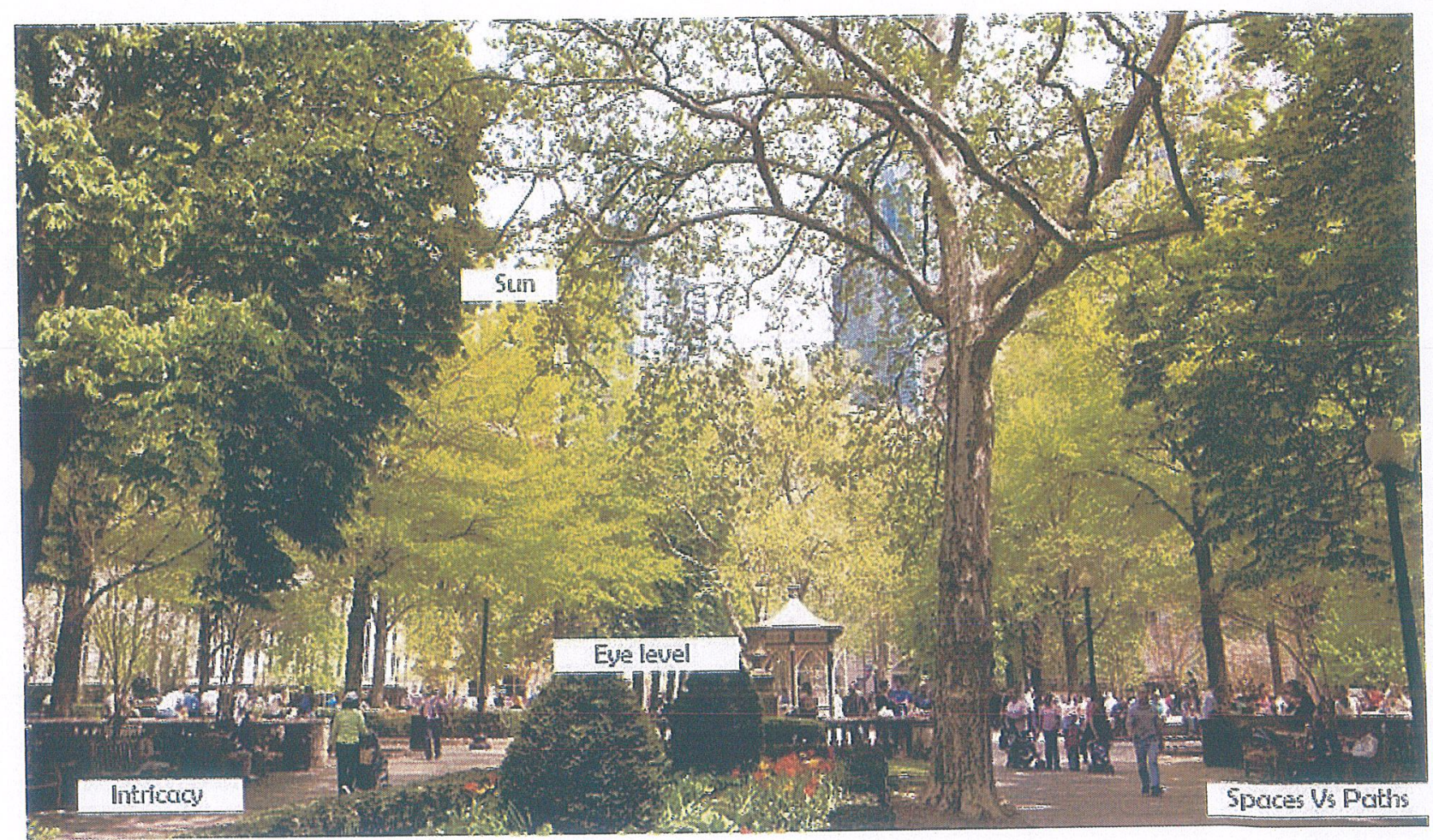

Figure 11: Rittenhouse Park view from inside, Philadelphia, Pennsylvania.

This park is to date Philadelphia's most famous town square because of its features like walkways, plazas, relaxing spots for picnics, sunbathing and so on. Rittenhouse's location in the heart of the city center's most expensive and exclusive neighborhood does not stop it hosting dozens of events throughout the year to which people from other neighborhoods come and participate. Some of the patterns used to make it even more unique consist of goals or aims for its urban space which can be listed as preserve, protect and beautify. These can be used in Jardin Public to meet the crucial need for preservation, protection, and maintenance as was recommended from the research done in the park (Kitheka, 2017).

The last park that was studied in this project is one of the most known and visited parks in the country, Central Park in New York, NY. Even though it has way more significance in scale to Jardin public, central park has many features that could potentially be placed in Jardin Public for the revival of the place. The park hosts a lot of programs and activities and it gives an excellent example of concepts like centering and scale for such a big urban space. Although it is a compact and multifunctional park (intricacy), people can enjoy the spaces in the park, orient themselves when needed because of how natural and well designed the place is. Furthermore, everything in the park is programmed and designed to be experienced and enjoyed at eye level so that the place does not become overwhelming to the users. 


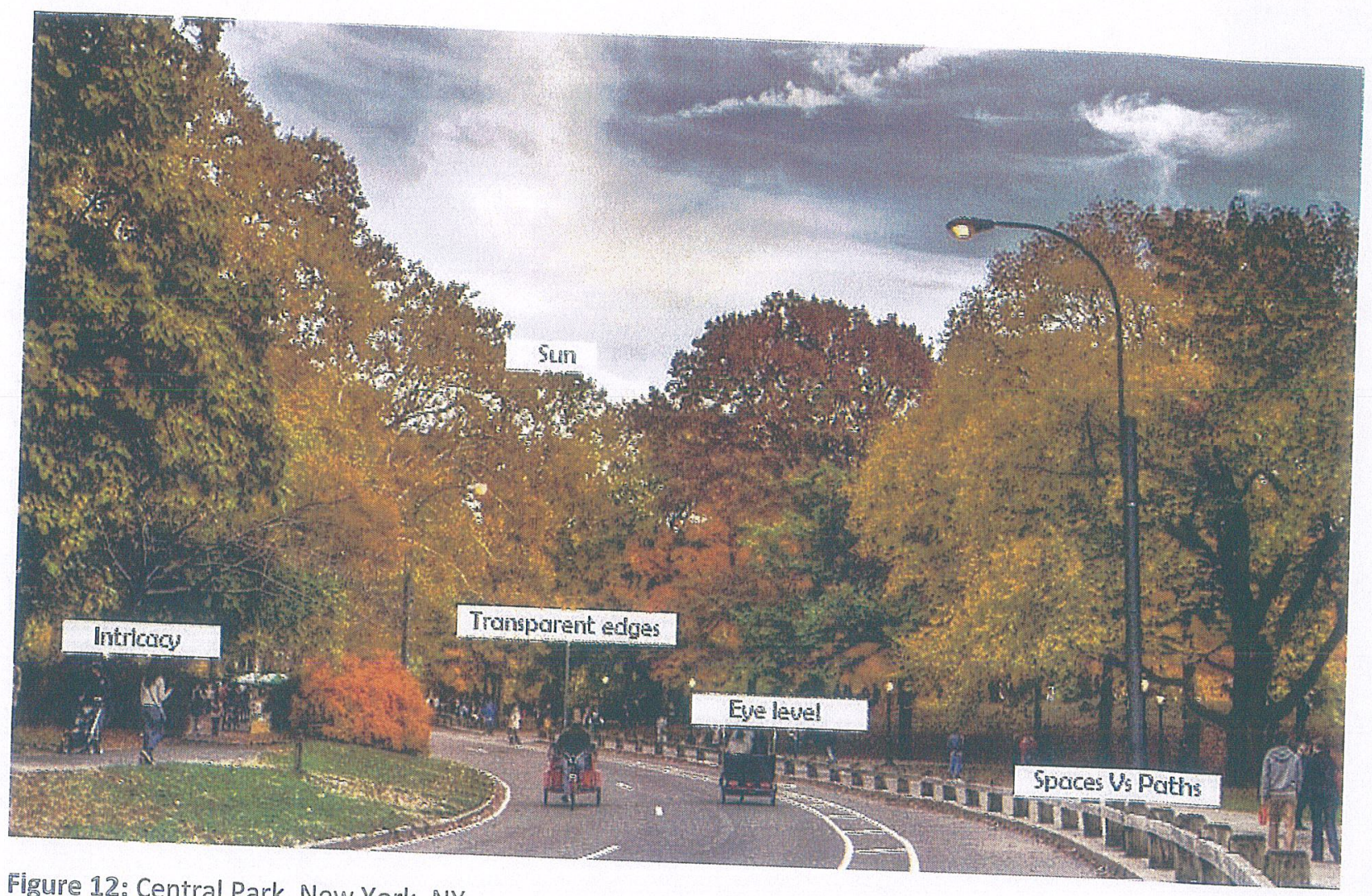

Figure 12: Central Park, New York, NY.

Both of these parks express various patterns and principles in their design that would be revolutionary to have in Jardin Public. They both have very attractive, inviting entrances and transparent edges in addition to a feeling of safety that they have without being fenced in (enclosure). They both have a great sense of
hierarchy and zoning that encourages the users to always come back for more.

\section{Tool Box}

\section{A. Toolbox concise} would attest a possibility for the possibility in terms of occurrence and stimulus to the community. It compared to how they do today. Moreover, with fhe safe and enjoy the park of their neighborhood public, with the analogy of placemaking in mind, I used a premise of making the park visited more and kept types of spaces: 1. public spaces with lim in which the design patterns and principled access and 2. public spaces. These would become umbrellas park. 
The public spaces with limited access would be public spaces that can be fenced and enclosed during certain hours of the day but open and accessible by anyone during appropriate hours. These places would have a specific role to play in the mission of the park and would be intentionally designed to engage a specific reservoir of users. Public spaces, on the other hand, will not be fenced in at all for their main purpose will be to engage people from the streets to use the park, making the parks entrances more inviting and providing places for people to interact, socialize and be a community without the need to use specific programs in the park.

Furthermore, redesigning the park with these two special categories in mind, will enable the designer to set parameters that will empower him to base all the design decisions for the main aim of a betterdesigned park. It would make the decision making more intentional and precise to the cause of attaining principles like centering, intricacy, the order of priorities as well as the scale at eye level, delight, comfort, and protection.

For instance, to eradicate the idea that the Jardin Public needs to be fenced for security purposes and the fact that people only go to the park because of activities or events; this would not be the case if these two spaces could be designed with the design concept of transparent edges and inviting entrances. Moreover, the idea of redesigning the park more intentionally with a clear goal could also enable the designer to implement patterns like identity and more importantly making the park a self-sustainable entity.

\section{B. Design Principles and the design Patterns}

For the toolbox with the two types of spaces, there can be different design concepts that can provide guidelines and prove the likelihood of attaining the initial goal of the project of having the park kept public yet self-sustainable, enjoyable and used by the neighborhood. I used both design principles, and design patterns learned from the case studies above so to inspire specific tools that could be used in the redesigning of the park. Understanding these two terms is crucial to knowing why and how these design concepts can be used in the redesigning of the park. Design principles are usually core abstract level of guidelines that one is supposed to follow when designing, while design patterns are found solutions to be identified and named occurring problems that will specifically be implemented in design to solve that problem. Design principles give guidelines to a better design while design principle suggests specific implementation for specific problems.

From the study, there were six design principles and four design pattern that was strongly emphasized by both the case studies and the literature reviews. Below are the design principles, their definitions and the reason why they will be needed in the redesigning of the park:

Sun: In addition to the climate factor done in this research, if you've ever been to Bujumbura you would know that you would not want to be in a space for so long without the opportunity to find refuge from the sun. Bujumbura being closer to the equator and in the south hemisphere categorizes itself as a warm country, for in almost every season of the year (average temperature of 86 degrees). Therefore, the redesigning of the park will need to include shaded spaces and the opportunity to ensure that the users do not suffer from the sun while using the park. 
Intricacy: As mentioned above, this relates to the variety of reasons for which people would want to come to the park. It is a concept of diversity of opportunities of programs for the users to anticipate for the perception parks. People come at different times, for different types of reasons and with a different of satisfaction of the users in the satisfied. The research that was conducted in the park tackled the level which would also attract more users to the park.

Centering and enclosure: In addition to intricacy being probably the most important and the most relevant to be considered in the redesigning of the park, as Jane Jacobs explains, centering is probably the most important element in intricacy. She believes that good small parks typically have a place within them while redesigning the parstood as centers. This principle would involve the use of hierarchy and zooning main crossroad, pausing points, and climax spaces.

Scale and eye level: Jane Jacobs's observation of the intricacy principle is that it is related to scale and eye level, she quoted: "intricacy that counts is mainly intricacy at eye level." Having many programs and activities going on in the park can be hard to control for the people in charge and could also be overwhelming to the users while using them. Thus, the principle of scaling everything down to people's eye level is very important and should be well-thought-out while redesigning Jardin Public de Bujumbura.

Order of priorities: Over the years, before its reopening, the park had a different reputation than the one found in the previous research done in 2017, only six years after the reopening. However, if the goal is to develop the park towards reaching its best potential, then this is the best time to reconsider the priorities of this park in terms of function, users, and aim. The redesigning should be viewed as an opportunity to revive the place and as an occasion to cultivate what was growing through the park's existence both when it was closed and now that it is opened. The reordering of priorities will enable the designer and the potential sponsors to be more intentional and thoughtful when answering the why, where, how and for who questions before taking on the project of redesigning this park.

Delight, comfort \& protection: The last principle that needs to be considered in the decision making of this redesigning process is the simple but complex design theory that places should provide delight, comfort, and protection to the parks' users. These are the most fundamental concepts that would assure that the redesigning is not just for the sake of redesigning, but the idea that this place is for the people. It reassurance that they will experience these of the park will depend merely on the users having the to be what it is meant to be in the first place.

Below are the four design Patterns:

Self-sustainability: Another main reason why there is no diversity of users is because of the current situation of an entry fee. Even though the entry fee is viewed as minimal to many people, in a country with $50 \%$ of the population being below the age of 18 years old, it would be an understatement to say that the entry fee does not affect the reservoir of users. However, this entry fee can very much be of this restricted access is harmful to pair and maintain the park and its facilities. However, the efficiency in the redesigning of this park for the purpose of the park. Therefore, it will take a strategical approach 
Inviting entrances: Currently, the park is fenced and has only one main entrance (See figure 1). Other historical entrances were closed and restricted so that they can control this one entrance. However, this is a significant limitation to the park being able to attract more users, especially since all the surrounding roads are both pedestrian and automobile friendly and could be an opportunity for enlarging the reservoir of users.

Even though the reason for this is understandable to some extent, I believe that if one is not welcomed at the entrance, the chances are that he/she is not going to enter or stay in the place for long. Moreover, naturally, people are more attracted to where they are given a chance to choose for themselves where to go. Therefore, the chances that the park would attract more people than the minimum is to provide choices not only by using the principle of intricacy in its inside but to intentionally provide a variety of inviting entrances. For it would take someone first to be willing to enter to enjoy the rest inside.

Transparent edges: As mentioned above, the park is surrounded by roads that are both pedestrian and automobile friendly, there is light traffic on the roads frequently used by the neighborhood residents. The existing fence was added when the French embassy and the ACVE decide to rehabilitate the park. (See figure 3). For them, it was one way to ensure safety in the park by controlling the perimeters and the entrances of the park. However, the fact that it is now fenced does not attract people but instead repels them, hence it limits the number of users that are willing to use the park and explore the park more.

In addition to the fencing of the park, the parameters of the park itself are not transparent and do not allow people to see what goes on in the park without going in it. However, as Jan Gehl discusses in his book, people go where other people are; like in children's' games, one child has to start, and everybody will eventually join - it is a self-reinforcing process. Therefore, creating transparent edges will remove the idea and doubt of the place being scary and also would invite more people to come, and more people will invite more people.

The rediscovery of Identity: Jane Jacobs highlights that to encourage the use of a park in a depressed area, the park should be designed for a specific reason, audience or goal and not just for general purposes. She argues that instead of just having an area for people to congregate rarely, there should be a purpose behind it.

With the history of the place and the core purpose of this idea of redesigning the park, it would be a mistake to redesign it and assume that everyone will be interested in it. I believe that the only way this park would be able to survive especially since the instability in the country is not over, the redesigning of the park has to have a uniqueness in what it offers. Redesigning the park should not only be about the play and recreation activities but should be a channel message that would speak to every Burundian heart. My recommendation with this pattern would be to stress the necessity of adding to the overall aim of redesigning Jardin Public for a rediscovery of identity. In my opinion, even though Jardin Public today is not recognized as a historical park because of how its existence was on and off, it never had a chance to prove its potential and ability to positively impact the community more than it does now. I believe that the park would be large enough in terms of scale to add a component of regaining, relearning and rediscovering Bujumbura's history, culture, and tradition. This would also help in the healing of the community. This approach would also attract tourists to the park and would hence be an additional source of income to the country as a whole. 


\section{Additional recommendations.}

As the results from this study showed, it is by redesigning Jardin Public de Bujumbura using a placemaking analogy and a level of intentionality that the project's vision of community connection and growth can be promoted. If at all possible, in addition to the different programs that Jardin Public currently hold, some suggested elements and programs can be drawn from this study and easily be added to attain the goal of Jardin public promoting the restoration of the city's sense of community.

For example, a market place with rentable spaces to vendors, if added could help the park become selfsustainable without the necessity of charging an entry fee. Work out spaces including basketball courts or a fitness area would work hand in hand with the existing running track (public) to encourage a healthy living program and recreation space for the youth. The park could also have green spaces with tall and/or small trees to provide breezy outdoor spaces for sitting, relaxing or having picnics; and these would become places that promote people's interactions, connections and encourage community-based
activities and enjoyments.

Additionally, the project could also have playgrounds for children to play in, where children games can be featured to entertain kids and to accommodate the family member that brought them. Moreover, as I

\section{Summary and conclusion.}

\section{A. Discussion and limitations}

My experience as an architecture student and researcher about the effect of public space in a community made me believe in design as a potential contributor to solving social problems. Different studies of public spaces have proved to many that they have a positive effect and contribution to the wellbeing of the cultural difference and the The limitations of this study, based upon the case studies, would involve the result.

In addition to the principles, patterns, remarks, and concepts about city parks' influence and use to their respective neighborhood that can be drawn from Jane Jacob's book; she claims that way too much is parks and should be viewed as local public that neighborhood parks are the most generalized form of city "parks are not automatically anything and yards not necessarily real estate stabilizers; she also states that or their neighborhoods and districts." Another lime least of all these unstable elements stabilizers of values eventually be directly and drastically affected limitation is that the neighborhood parks themselves will either well designed or not, it would highly depend way the neighborhood acts upon them. Therefore, the Parks' main goal and purpose achieved. 
It is also essential to understand that cities and their parks influence each other very much, especially when the park might be viewed as one potential vessel to promote a revival, connection and development of a neighborhood like Rohero I and later the city of Bujumbura. As Jane Jacobs highlights, "Neighborhood parks fails to substitute in any way for plentiful diversity" therefore, Jardin Public might be one potential channel towards the healing of the Bujumbura community but should not be perceived as the only one or the most important one.

\section{B. Future recommendations}

Although not studied, it may be inferred from this study that the existing architecture and urban design of the city might have a significant impact on the current tensions and civil instability in both the city and the country as a whole. Further studies should examine the outcomes that urban development could have on the healing of Burundian communities. 


\section{Bibliography}

Alexander, Christopher. A Pattern language: Towns, Buildings, Construction. New York: Oxford University
Press, 1977. Burundi Population 2019. (2019, February 17). Retrieved April 2, 2019, from

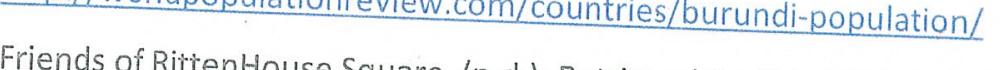

Jacobs, Jacobs, J. (1992). The death and life of great American cities: Orig. publ. 1961. New York: Vintage Durban,2014

Kitheka, B.M., Mcguire, F.A., Nibigira, C. \& Mgonja, J.T. (2017). Play and recreation in a developing country context: Assessing utility of Jardin public gardens, Bujumbura, Burundi. African Journal for Physical Activity
and Health Sciences, $23(4), x \times-x \times$. Matan, A., \& Newman, P. (2016). People cities: The life and legacy of Jan Gehl. Washington, DC: Island Press. Parc - Jardin - LE JARDIN PUBLIC - Bujumbura. (2018, December 04). Retrieved February 4, 2019, from https://www.petitfute.com/v48503-bujumbura/c1173-visites-points-d-interet/c971-parc-jardin/430600-
le-jardin-public.html Park am Gleisdreieck "Landezine International Landscape Award LILA. (2016). Retrieved from https://landezine-award.com/park-am-gleisdreieck/
The St Stephen's Green Park Blog. (n.d.). Retrieved April 4, 2019, from http://ststephensgreenpark.ie/ Toloudi, Z. (2018, December 10). Are we in the midst of a public space crisis? Retrieved January 10, 2019 , from https://theconversation.com/are-we-in-the-midst-of-a-public-space-crisis-56124

Violich, F. (1985). Towards revealing the sense of place: An intuitive "reading" of four Dalmatian towns. White, G. (2015). Africa drawn. One hundred cities. Berlin: DOM.

\section{Images citations:} Figure 6: World Weather Online. (n.d.). Retrieved from https://www.worldweatheronline.com/lang/en-
us/bujumbura-weather-history/bujumbura/

Figure 7: Destination, M. (n.d.). Mogadishu Peace Parka, Holiday Garden. Retrieved April 4, 2019, from https://www.visitmogadishu.com/dt places/mogadishu-peace-parka-holiday-garden/ Figure 8: The Pedestrianization of Greenmarket Square and the Rejuvenation of Inner-City Cape Town.
(2016, November 07). Retrieved April 4, 2019, from https://theurbanweb.wordpress.com/2016/11/07/the-pedestrianisation-of-greenmarket-square-and-

Figure 9: File: Dublin Stephen's Green-44 edit.jpg. (2017, December 02). Retrieved April 4, 2019, from https://en.wikipedia.org/wiki/St Stephen's Green\#/media/File: Dublin Stephen's Green-44 edit.jpg Figure 10: Park at Gleisdreieck. (2016). Retrieved from https://www.visitberlin.de/en/park-gleisdreieck Figure 11: Rittenhouse Square. (n.d.). Retrieved April 1, 2019, from https://www.visitphilly.com/things-Figure 12: Photo entry: The road of eternal bliss! (2009, October 28). Retrieved April 4, 2019, from
https://www.centralpark.com/photo-contest/road-eternal-bliss/ 